\title{
Reproductive variability of the common snook, Centropomus undecimalis, in environments of contrasting salinities interconnected by the Grijalva-Usumacinta fluvial system
}

\section{Variabilidad reproductiva del robalo común, Centropomus undecimalis, en ambientes de salinidad contrastante interconectados por el sistema fluvial Grijalva-Usumacinta}

\author{
Ulises Hernández-Vidal ${ }^{1,2}$, Xavier Chiappa-Carrara³, Wilfrido Contreras-Sánchez ${ }^{2 *}$ \\ 1 Posgrado en Ciencias del Mar y Limnología, Unidad Académica Sisal, Universidad Nacional Autónoma de \\ México, Sisal, Yucatán, 97355, México. \\ ${ }^{2}$ División Académica de Ciencias Biológicas, Universidad Juárez Autónoma de Tabasco, Carretera \\ Villahermosa-Cárdenas km 0.5, Villahermosa, Tabasco, 86280, México. \\ 3 Unidad Multidisciplinaria de Docencia e Investigación, Unidad Académica Sisal, Universidad Nacional \\ Autónoma de México, Sisal, Yucatán, 97355, México.
}

* Corresponding author. E-mail: contrerw@hotmail.com

\begin{abstract}
The common snook, Centropomus undecimalis, is a migratory euryhaline fish. In the southern Gulf of Mexico, fishing of large snooks occurs mainly in the marine environment (MA), while medium-size adults and juveniles are caught in freshwater environments (FW); however, large-size adults can also be found in FW far away from the sea, and the effect of different environments on their reproductive cycle is unknown. To describe the reproductive cycle of this species in different salinity habitats, we analyzed macroscopic reproductive characteristics during one annual cycle in FW and MA interconnected by the Grijalva-Usumacinta basin. Specimens with full-grown gonads and capable of spawning were found in FW, an unusual condition not reported for this habitat, but active spawning was observed only in MA. Centropomus undecimalis has a biological strategy that allows the use of FW as a juvenile until it reaches sexual maturity as a male and joins the reproductive stock in MA. Adults of both sexes can remain in both FW and MA without affecting their reproductive cycle, suggesting that those that mature in FW migrate to the sea during the spawning season.
\end{abstract}

Key words: reproductive biology, contrasting environments, Centropomidae, common snook, Centropomus undecimalis.

RESUMEN. El robalo común, Centropomus undecimalis, es un pez eurihalino migratorio. En el sur del golfo de México, los adultos dominan la captura en ambientes marinos (AM) mientras que los adultos jóvenes y juveniles se capturan en ambientes dulceacuícolas (AD); sin embargo, se pueden encontrar adultos de gran talla y edad en $\mathrm{AD}$ alejados del mar, y se desconoce el efecto del ambiente contrastante sobre su ciclo reproductor. Para conocer el efecto de los hábitats de salinidad contrastante en el robalo común, se analizaron características reproductoras macroscópicas durante un ciclo anual en AM y AD interconectados por la cuenca Grijalva-Usumacinta. Se localizaron ejemplares con gónadas bien desarrolladas y capaces de desovar en $\mathrm{AD}$, condición no convencional en este hábitat, pero el desove activo sólo se observó en AM. Centropomus undecimalis muestra una estrategia biológica que le permite aprovechar el AD como juvenil hasta alcanzar la madurez sexual como macho y luego incorporarse al stock reproductor en AM. Los adultos de ambos sexos permanecen indistintamente en AM o AD sin haber efectos sobre su ciclo reproductor, sugiriendo que aquellos que maduran en $\mathrm{AD}$ migran al mar durante la temporada de desove.

Palabras clave: biología reproductora, ambientes contrastantes, Centropomidae, robalo común, Centropomus undecimalis

\section{INTRODUCTION}

The common snook, Centropomus undecimalis, is a migratory euryhaline fish distributed along the coasts of the Atlantic Ocean, the Gulf of Mexico, and the Caribbean Sea (Tringali and Bert 1996, Tringali et al. 1999, Taylor et al. 2000, Perera-García et al. 2011). Snooks are protandric hermaphrodites that spawn from April to September in the coastal marine environment, estuaries, and lagoons with salinities of 28 to 35 (Grier 1985; Tucker 1987; Taylor et al. 1998; Perera-García et al. 2008, 2011, 2013). Larvae and

\section{INTRODUCCIÓN}

El robalo común, Centropomus undecimalis, es un pez eurihalino y migratorio que se distribuye a lo largo de las costas del océano Atlántico, golfo de México y mar Caribe (Tringali y Bert 1996, Tringali et al. 1999, Taylor et al. 2000, Perera-García et al. 2011). Los robalos son peces hermafroditas protándricos que desovan de abril a septiembre en ambientes costeros y marinos, estuarios y lagunas costeras con salinidad de 28 a 35 (Grier 1985; Tucker 1987; Taylor et al. 1998; Perera-García et al. 2008, 2011, 2013). Las larvas 
fry migrate into estuaries and rivers, where part of their development as juveniles and adults takes place. After gonadal maturity, they return to the sea and join the reproductive stock (McMichael et al. 1989, Tringali and Bert 1996).

Centropomus undecimalis is a fishery resource exploited in various habitats. Due to its commercial value, its catch in Mexico is intense in its main fishing area in the southern Gulf of Mexico, mainly along the coasts of Campeche, Tabasco, and Veracruz. Recent reports have indicated a decrease in its fishery production and the need to implement management programs before a possible reduction of the local stocks occurs (Perera-García et al. 2008, 2011). Behavioral patterns such as reproductive aggregations along the coast and seasonal migrations in the fluvial systems seem to increase the vulnerability of $C$. undecimalis by facilitating its capture (Perera-García et al. 2011).

The Grijalva-Usumacinta fluvial system interconnects ample areas of southeastern Mexico and Guatemala. Specimens of C. undecimalis - of reproductive sizes and ages - are collected in the system, both in the marine environment adjacent to the inlet and in freshwater environments, in areas more than $300 \mathrm{~km}$ away from the sea (Perera-García et al. 2008, 2011; Hernández-Vidal et al. 2014). The presence of adult fishes of advanced ages and sizes in systems with such contrasting conditions generates questions on the possible influence of these conditions on reproduction, and on how this effect is reflected in the organisms' characteristics during the year. The purpose of this study was to describe and compare the morphometric and reproductive characteristics of specimens collected in geographically distant environments with contrasting salinities. A recent study (HernándezVidal et al. 2014) identified that snooks from these contrasting environments belong to the same genetic stock. The information gathered will contribute to knowledge of the biology of the species, in the framework of these environmental conditions, providing elements for an integral management program to be used by the fishing communities.

\section{MATERIALS AND METHODS}

Between April 2010 and March 2011, 507 C. undecimalis specimens were collected using gill nets in two fishery areas in Tabasco, Mexico (fig. 1). One was located in the coastal area, called marine environment (MA) for this study, and the other in the main channel of the San Pedro River, a tributary of the Grijalva-Usumacinta system, called freshwater environment (FW). An approximate distance of $300 \mathrm{~km}$ separates the sampling localities. At each sampling locality, we recorded the geographical location with a GPS (Garmin) and the depth with an echosounder (NorCross Marine Products, Inc., USA). Surface, mid-depth, and bottom water samples were collected with a Van Dorn sampler (Wild Co., USA) in order to record physicochemical parameters. The data recorded included dissolved oxygen and temperature, measured with a field oxymeter (YSI model 95); and salinity, y crías migran hacia estuarios y ríos donde se desarrollan como juveniles y adultos. Se considera que después de alcanzar la madurez gonádica, regresan al mar para incorporarse al banco reproductor (McMichael et al. 1989, Tringali y Bert 1996).

Centropomus undecimalis es un recurso pesquero explotado en diversos hábitats. Debido a su valor comercial, la captura en México es intensa en las principales zonas de pesca en el sur del golfo de México, principalmente en las costas de Campeche, Tabasco y Veracruz. Los registros recientes indican una disminución en la producción pesquera y la necesidad de implementar un programa de manejo ante la posible reducción de las poblaciones pesqueras locales (Perera-García et al. 2008, 2011). Los patrones de conducta como las agregaciones reproductivas a lo largo de la costa y las migraciones estacionales en los sistemas fluviales, aparentemente incrementan la vulnerabilidad de $C$. undecimalis al facilitar su captura (Perera-García et al. 2011).

El sistema fluvial Grijalva-Usumacinta interconecta amplias áreas del sureste de México y Guatemala. Ejemplares de C. undecimalis - de edad y talla reproductiva - son recolectados en el sistema, tanto en el ambiente marino adyacente a su descarga al mar como en el ambiente dulceacuícola, en áreas alejadas de la costa a más de $300 \mathrm{~km}$ (Perera-García et al. 2008, 2011; Hernández-Vidal et al. 2014). La presencia de peces adultos de avanzada edad y gran tamaño en un sistema con condiciones contrastantes genera interrogantes sobre el posible efecto de estas condiciones sobre la reproducción, y sobre cómo este efecto se refleja en las características de los organismos durante el año. El propósito de este estudio fue describir y comparar las características morfométricas y reproductivas de ejemplares recolectados en hábitats geográficamente distantes y con salinidad contrastante. El estudio reciente de HernándezVidal et al. (2014) indica que los robalos provenientes de estos ambientes contrastantes pertenecen a una misma población genética. La información obtenida contribuirá al conocimiento de la biología de esta especie, en el contexto de estas variaciones ambientales, aportando elementos para el desarrollo de un programa de manejo integral que pueda ser empleado por las comunidades pesqueras.

\section{MATERIALES Y MÉTODOS}

Entre abril de 2010 y marzo de 2011 se recolectaron un total de 507 ejemplares de $C$. undecimalis con redes agalleras en dos áreas de pesca en Tabasco, México (fig. 1). Una de las áreas se localizó en la zona costera, denominada en este estudio ambiente marino (AM), y la otra en el cauce principal del río San Pedro, un tributario del sistema Grijalva-Usumacinta, denominado ambiente dulceacuícola (AD). Ambas localidades de muestreo están separadas por una distancia aproximada de $300 \mathrm{~km}$. En cada punto de muestreo, se registró la ubicación geográfica con un GPS (Garmin) y la profundidad con una ecosonda (NorCross Marine Products, Inc., EUA). 


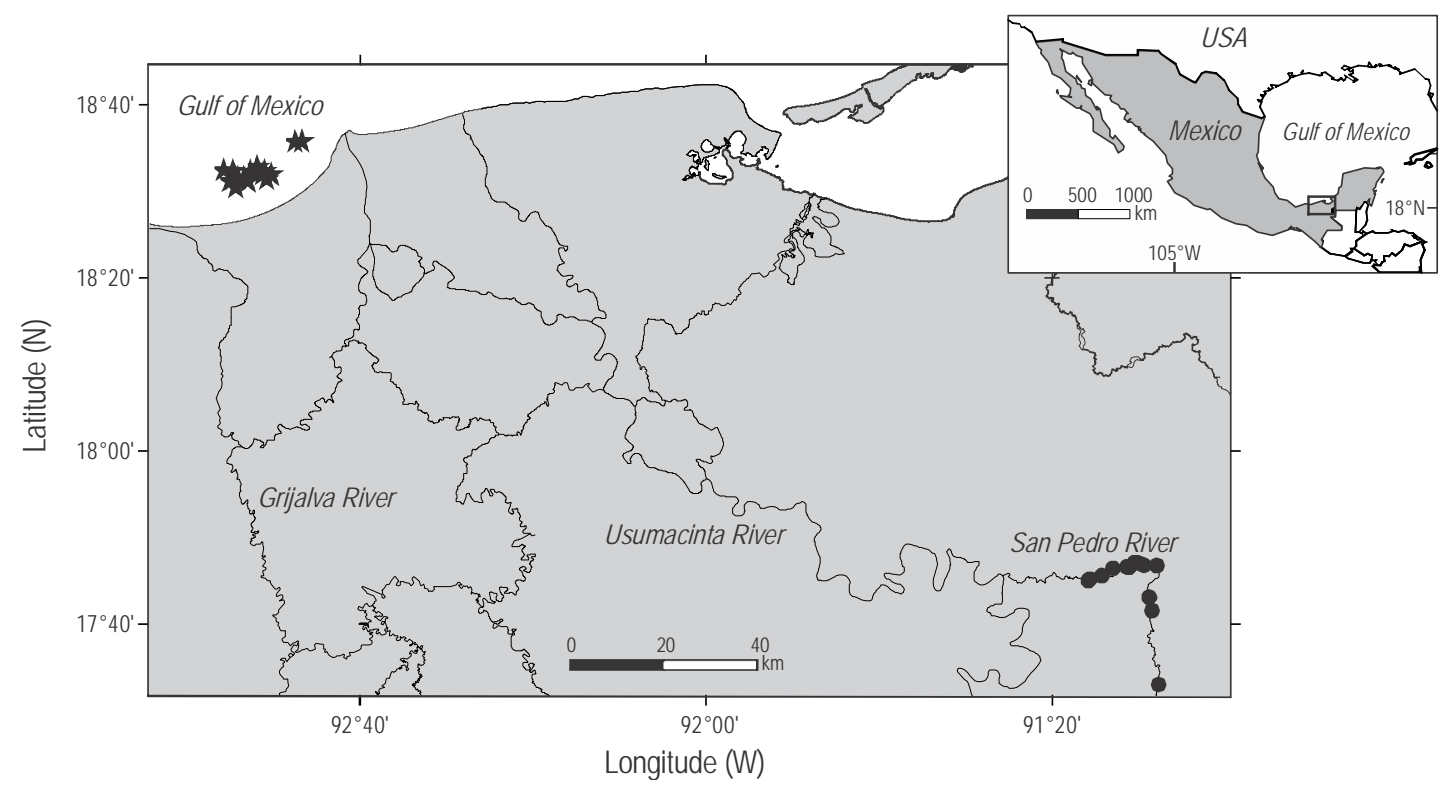

Figure 1. Sampling localities for Centropomus undecimalis along the coast of the Gulf of Mexico (marine environment, $\star$ ) and along a tributary of the Grijalva-Usumacinta system (freshwater environment, $\bullet$ ).

Figura 1. Localidades de muestreo de Centropomus undecimalis a lo largo de la costa del golfo de México (ambiente marino, $\star$ ) y a lo largo de un tributario del sistema Grijalva-Usumacinta (ambiente dulceacuícola, $\bullet$ ).

electric conductivity, and total dissolved solids, measured with a conductimeter (HI9835 Hanna Instruments). Fish were collected with gill nets, with a mesh size of 3 to 6 inches. Total length (TL, $\mathrm{cm} \pm 1.0)$, standard length ( $\mathrm{cm} \pm 1.0)$, and total weight (TW, $\mathrm{kg} \pm 0.001$ ) were recorded for each specimen. The gonads were extracted and weighed, and the sex was determined by macroscopic observation.

The macroscopic stages of gonadal maturity were defined following the criteria of Brown-Peterson et al. (2011), considering the following phases: (I) immature, fish that never spawned; (II) developing, fish with growing gonads but not ready to spawn; (III) spawning capable, fish with a completely developed gonad that could spawn during the cycle, including the actively spawning subphase for those found spawning; (IV) regressing, cessation of spawning; and (V) regenerating, sexually mature fish that are reproductively inactive. The total length at which $50 \%\left(\mathrm{~L}_{50}\right)$ of the specimens actively play a role in reproduction was calculated following Vazzoler (1996), using the accumulated frequency of reproductive stages for each size interval and adjusting it to a logistic function, according to the suggestions of Gayanilo and Pauly (1997). The gonadosomatic index $\left(\mathrm{I}_{\mathrm{G}}\right)$ was estimated following Bagenal and Tesch (1978) and Vazzoler (1996).

The weight and size of the specimens were analyzed with the Kolmogorov-Smirnov test (KS), while the sex ratios (M:F) per environment, month, and size intervals were compared with the $\chi^{2}$ test (Zar 1999). Fulton's general condition factor $\left(\mathrm{K}_{\mathrm{F}}\right)$, the total condition factor $\left(\mathrm{K}_{\mathrm{T}}\right)$, and the somatic condition factor $\left(\mathrm{K}_{\mathrm{S}}\right)$ were calculated monthly for
Para el registro de los parámetros fisicoquímicos, se recolectaron muestras de agua de la superficie, la profundidad media y el fondo con una botella muestreadora tipo Van Dorn (Wild Co., EUA). Los datos registrados incluyeron el oxígeno disuelto y la temperatura, que fueron determinados con un oxímetro de campo (YSI modelo 95), además de la salinidad, la conductividad eléctrica y los sólidos disueltos totales, que fueron medidos con un conductivímetro (HI9835 Hanna Instruments). Para la recolecta de los peces, se utilizaron redes agalleras con luz de malla de 3 a 6 pulgadas. Se registró la longitud total $(\mathrm{LT}, \mathrm{cm} \pm 1.0)$, la longitud estándar $(\mathrm{cm} \pm 1.0)$ y el peso total (PT, $\mathrm{kg} \pm 0.001)$ de cada ejemplar. Las gónadas fueron extraídas y pesadas, y el sexo fue determinado por observación macroscópica.

Las etapas de madurez gonádica fueron definidas siguiendo el criterio de Brown-Peterson et al. (2011), considerando las siguientes etapas: (I) inmadura, peces que nunca han desovado; (II) en desarrollo, peces con gónadas en crecimiento pero que no están listos para el desove; (III) capaz de desovar, peces con una gónada completamente desarrollada que puede desovar durante la temporada, e incluye la subetapa desove activo para los que se capturaron desovando; (IV) en regresión, peces que han terminado de desovar; y (V) en regeneración, peces sexualmente maduros pero reproductivamente inactivos. Para determinar la LT a la cual el $50 \%\left(\mathrm{~L}_{50}\right)$ de los ejemplares participa activamente en la reproducción, se emplearon los cálculos propuestos por Vazzoler (1996), utilizando la frecuencia acumulada de las etapas de madurez para cada intervalo de talla y ajustada a la función logística de acuerdo con lo sugerido por Gayanilo y 
each environment and sex following Bagenal and Tesch (1978) and Vazzoler (1996). These indices were compared throughout the year using the Kruskal Wallis test (KW). The weight-length relationship was calculated with a potential regression based on the equation $\mathrm{TW}=a \mathrm{TL}^{b}$, where $\mathrm{TW}$ is the total weight of the fish in grams, $a$ is the regression constant, TL is the total length in centimeters, and $b$ is the regression coefficient (Gayanilo and Pauly 1997). Considering that the $b$ coefficient provides information on the type of growth of the species, $b=3$ is isometric and $b \neq 3$ is allometric (Bagenal and Tesch 1978). The value was analyzed with the Student $t$ test (Zar 1999) and the hypotheses Ho: $b=3$ and Ha: $b \neq 3$ were established. In all cases, statistical analyses were carried out at a significance level of 0.05 (Zar 1999).

\section{RESUltS}

The 507 specimens collected included 240 from MA and 267 from FW. The males were significantly smaller than the females in size and weight, both in $\mathrm{FW}(\mathrm{KS}=2.8,3.1$; $P<0.001)$ and MA $(\mathrm{KS}=2.8,2.6 ; P<0.001)$. Fish of both sexes were bigger in weight and size in MA than in FW (KS, $P<0.05$ ). In FW, males varied from 39 to $89 \mathrm{~cm} \mathrm{TL}$ $(0.50-4.5 \mathrm{~kg}$ TW) and females from 55 to $110 \mathrm{~cm} \mathrm{TL}$ (0.90-10.75 kg TW). In MA, males varied from 74 to $101 \mathrm{~cm}$ TL (3.09-7.73 kg TW) and females from 70 to $114 \mathrm{~cm} \mathrm{TL}$ (3.11-11.30 kg TW).

The TW-TL relationship of all the specimens (fig. 2) produced the general equation TW $=-5.114(\mathrm{TL})^{3.04}$, with $94 \%$

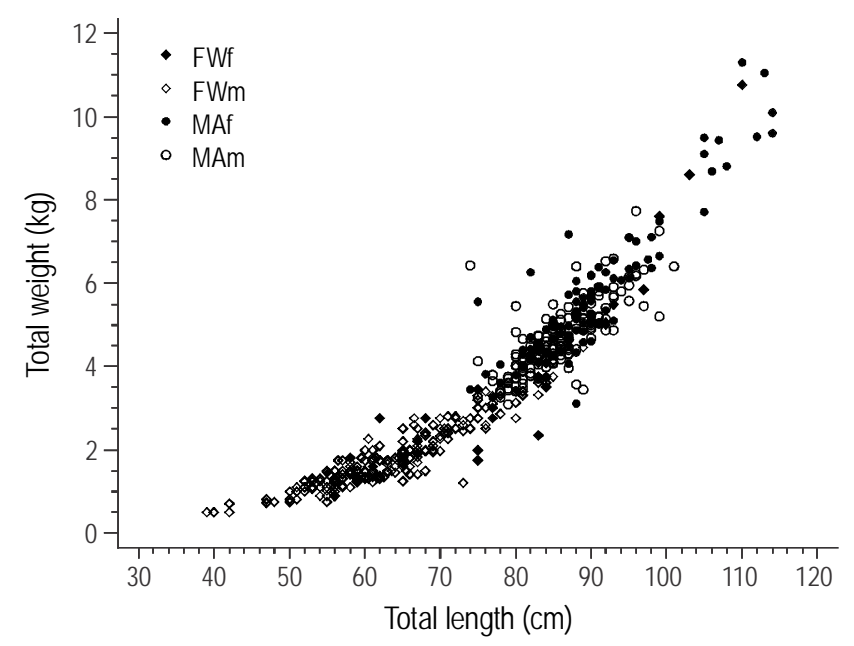

Figure 2. Total weight-total length relationship for all Centropomus undecimalis sampled: males and females from a marine environment (MAm and MAf, respectively), and males and females from a freshwater environment (FWm and FWf, respectively).

Figura 2. Relación peso total-longitud total para todos los ejemplares de Centropomus undecimalis muestreados machos y hembras del ambiente marino (MAm y MAf, respectivamente), y machos y hembras del ambiente dulceacuícola (FWm y FWf, respectivamente).
Pauly (1997). El índice gonadosomático $\left(\mathrm{I}_{\mathrm{G}}\right)$ fue estimado con base en la propuesta de Bagenal y Tesch (1978) y Vazzoler (1996).

El peso y la talla de los ejemplares fueron analizados con la prueba de Kolmogorov-Smirnov (KS), mientras que la proporción sexual $(\mathrm{M}: \mathrm{H})$ por ambiente, mes e intervalos de talla fueron comparados con la prueba $\chi^{2}$ (Zar 1999). El índice de condición general de Fulton $\left(\mathrm{K}_{\mathrm{F}}\right)$, el índice de condición total $\left(\mathrm{K}_{\mathrm{T}}\right)$ y el índice de condición somática $\left(\mathrm{K}_{\mathrm{S}}\right)$ fueron calculados mensualmente por cada ambiente y sexo, con base en la propuesta de Bagenal y Tesch (1978) y Vazzoler (1996). Estos índices fueron comparados a lo largo del año usando la prueba de Kruskal Wallis (KW). La relación peso-longitud fue calculada mediante una regresión potencial basada en la ecuación $\mathrm{PT}=a \mathrm{LT}^{b}$, donde PT es el peso total del pez en gramos, $a$ es la constante de la regresión, LT es la longitud total en centímetros y $b$ es el coeficiente de la regresión (Gayanilo y Pauly 1997). Considerando que el coeficiente $b$ provee información sobre el tipo de crecimiento de las especies, $b=3$ es isométrico y $b \neq 3$ es alométrico (Bagenal y Tesch 1978). Este valor fue analizado con la prueba de $t$ de Student y las hipótesis Ho: $b=3$ y Ha: $b \neq 3$ (Zar 1999). En todos los casos, el análisis estadístico se realizó empleando un nivel de significancia de 0.05 (Zar 1999).

\section{REsultados}

Los 507 ejemplares recolectados incluyeron 240 provenientes del AM y 267 del DA. Los machos fueron significativamente más pequeños que las hembras en talla y peso, tanto en $\mathrm{AD}(\mathrm{KS}=2.8,3.1 ; P<0.001)$ como en el $\mathrm{AM}(\mathrm{KS}=2.8$, 2.6; $P<0.001)$. Los peces de ambos sexos fueron más grandes en peso y talla en el AM que en el AD $(\mathrm{KS}, P<0.05)$. En el $\mathrm{AD}$, los machos variaron de 39 a $89 \mathrm{~cm}$ LT $(0.50-4.5 \mathrm{~kg}$ PT) y las hembras de 55 a $110 \mathrm{~cm} \mathrm{LT} \mathrm{(0.90-10.75} \mathrm{kg} \mathrm{PT).} \mathrm{En}$ el AM, los machos variaron de 74 a $101 \mathrm{~cm}$ LT (3.09-7.73 kg PT) y las hembras de 70 a $114 \mathrm{~cm} \mathrm{LT} \mathrm{(3.11-11.30} \mathrm{kg} \mathrm{PT).}$

La relación PT-LT de todos los ejemplares (fig. 2) permitió generar una ecuación general: $\mathrm{PT}=-5.114(\mathrm{LT})^{3.04}$, con un $94 \%$ de la variabilidad del peso explicada por el modelo. El crecimiento de la especie fue determinado como isométrico $(t=0.90, P=0.361)$.

Los machos predominaron significativamente en los dos ambientes. En total se recolectaron 383 machos (75.5\%) y 124 hembras (24.5\%), y la proporción M:H de 3:1 fue significativamente diferente de la proporción esperada de 1:1 $\left(\chi^{2}=26.1, P<0.05\right)$. En AD, se recolectaron 236 machos y 31 hembras, con una proporción M:H significativamente sesgada de 7.6:1 $\left(\chi^{2}=58.9, P<0.05\right)$. Los machos constituyeron más del $80 \%$ de las capturas mensuales en $\mathrm{AD}$, excepto en octubre (68\%). En AM, se recolectaron 147 machos y 93 hembras, y la proporción M:H fue de 1.5:1, significativamente menos sesgada $\left(\chi^{2}=26.1, P<0.05\right)$. En el AM se presentó una marcada variación mensual, con predominio 
percent of the weight variability being explained by the model. The growth of the species was isometric $(t=0.90$, $P=0.361)$.

Males were significantly predominant in both environments. We collected 383 males (75.5\%) and 124 females $(24.5 \%)$, the total M:F ratio of 3:1 being significantly different from the expected ratio of 1:1 $\left(\chi^{2}=26.1, P<0.05\right)$. In FW, 236 males and 31 females were collected, with a significantly skewed M:F ratio of 7.6:1 $\left(\chi^{2}=58.9, P<0.05\right)$. Males made up more than $80 \%$ of the monthly captures in $\mathrm{FW}$, except in October (68\%). In MA, 147 males and 93 females were collected, and the M:F ratio of 1.5:1 was significantly less biased $\left(\chi^{2}=26.1, P<0.05\right)$. The MA presented a marked monthly variation, with more males $(62-87 \%)$ in January, February, April, June, and July $\left(\chi^{2}=5.6-9.0, P<0.05\right)$; only females in September; and a similar sex ratio in March, August, November, and December $\left(\chi^{2}=0.83, P>0.05\right)$.

The sex ratio according to size indicated that there were more males of small sizes and more females of large sizes in both environments (fig. 3a-c). In MA, the sex ratio was higher for females of 70 to $74 \mathrm{~cm}$ and for males of 75 to $89 \mathrm{~cm}\left(\chi^{2}=7.5, P<0.05\right)$. There were no statistically significant differences for the size range of 90 to $104 \mathrm{~cm}\left(\chi^{2}=0.05\right.$, $P>0.05$ ), while only females were observed for lengths of $105 \mathrm{~cm}$ and larger (fig. 3a). In FW, the sex ratio was higher for males of 35 to $84 \mathrm{~cm}\left(\chi^{2}=18.3, P<0.05\right)$, similar for sizes of 85 to $89 \mathrm{~cm}\left(\chi^{2}=0.0, P>0.05\right)$, and only females were collected with lengths of $90 \mathrm{~cm}$ and larger, with females starting at $55 \mathrm{~cm}$ (fig. 3b). A total analysis provided a greater proportion of males of 35 to $89 \mathrm{~cm}\left(\chi^{2}=6.5, P<0.05\right)$, the same sex ratio (1:1) for sizes of 90 to $104 \mathrm{~cm}\left(\chi^{2}=0.1-0.7\right.$, $P>0.05)$, and only females for sizes of $105 \mathrm{~cm}$ and larger (fig. 3c).

The gonadal development evaluated by macroscopic examination indicated that in $\mathrm{FW}$, there were fish of both sexes in stages ranging from immature to spawning capable, and in MA, there were fish in developing to regressing stages (fig. 4a-d). Fish of both sexes in the spawning capable stage and the actively spawning subphase were found only in MA. We observed no organisms in the regenerating stage in either environment. In MA, the greatest frequency of individuals of both sexes in the developing stage was recorded from November to February, while those in the spawning capable stage occurred between February and August, with an apparent cessation of spawning starting in September (fig. 4a, b). The actively spawning subphase was observed in April $(40 \%)$, July (56\%), and August (100\%) in females, and only in August in the case of males (100\%). In FW, females presented the developing stage throughout most of the year and the spawning capable stage in April and September (fig. 4c). The FW males presented the developing stage during most of the year; however, males in the spawning capable stage were observed during the last months of the year (coinciding with the down-river migrations reported by fishers), with the majority observed in October (87.5\%; fig. 4d). de machos (62-87\%) en enero, febrero, abril, junio y julio $\left(\chi^{2}=5.6-9.0, P<0.05\right)$; exclusivamente hembras en septiembre; y una proporción sexual similar en marzo, agosto, noviembre y diciembre $\left(\chi^{2}=0.83, P>0.05\right)$.

La proporción sexual por talla indicó que en ambos ambientes hay mayor frecuencia de machos en los intervalos de tallas menores y predominio de hembras en los intervalos de tallas mayores (fig. 3a-c). En el AM, la proporción sexual fue mayor para las hembras en el intervalo de talla de 70 a $74 \mathrm{~cm}$ y para los machos en el de 75 a $89 \mathrm{~cm}\left(\chi^{2}=7.5\right.$, $P<0.05)$. No hubo diferencia significativa para el intervalo de 90 a $104 \mathrm{~cm}\left(\chi^{2}=0.05, P>0.05\right)$, mientras que sólo se observaron hembras para las tallas de $105 \mathrm{~cm}$ o superiores (fig. 3a). En el $\mathrm{AD}$, la proporción sexual fue mayor para los machos en los intervalos de talla de 35 a $84 \mathrm{~cm}\left(\chi^{2}=18.3\right.$, $P<0.05)$ y de 85 a $89 \mathrm{~cm}\left(\chi^{2}=0.0, P>0.05\right)$; las hembras se observaron a partir de los $55 \mathrm{~cm}$, y sólo se observaron hembras cuando las tallas fueron de $90 \mathrm{~cm}$ o superiores (fig. 3b). El análisis conjunto indica mayor proporción de machos en el intervalo de 35 a $89 \mathrm{~cm}\left(\chi^{2}=6.5, P<0.05\right)$, la misma proporción (1:1) para tallas de 90 a $104 \mathrm{~cm}$ $\left(\chi^{2}=0.1-0.7, P>0.05\right)$ y únicamente hembras para tallas de $105 \mathrm{~cm}$ o mayores (fig. 3c).

El desarrollo gonádico evaluado mediante el examen macroscópico indicó que en el $\mathrm{AD}$ se localizan peces de ambos sexos en las etapas desde inmadura hasta capaz de desovar y en el AM desde en desarrollo hasta en regresión (fig. 4a-d). Ejemplares de ambos sexos en la etapa capaz de desovar y en la subetapa desove activo fueron encontrados únicamente en el AM. No se observaron ejemplares en la etapa de regeneración en ninguno de los ambientes. En el $\mathrm{AM}$, la frecuencia más alta de individuos de ambos sexos en la etapa en desarrollo se registró desde noviembre hasta febrero, mientras que la etapa capaz de desovar se observó entre febrero y agosto, con cese en los desoves a partir de septiembre (fig. 4a, b). La subetapa desove activo se observó en las hembras en abril (40\%), julio (56\%) y agosto (100\%), mientras que en los machos sólo se observó en agosto $(100 \%)$. En el AD, las hembras generalmente presentaron la etapa en desarrollo a lo largo del año y la etapa capaz de desovar en abril y septiembre (fig. 4c). Los machos del AD presentaron la etapa en desarrollo durante la mayor parte del año; sin embargo, se observaron machos en la etapa capaz de desovar durante los últimos meses del año (coincidente con la migración río abajo reportada por los pescadores), la mayoría observados en octubre (87.5\%, fig. $4 d)$.

Los valores de los índices de condición evaluados a lo largo del año fueron más altos para los peces del AM. Los machos presentaron valores más altos que las hembras en ambos ambientes. El índice de condición general de Fulton $\left(\mathrm{K}_{\mathrm{F}}\right)$, el índice de condición total $\left(\mathrm{K}_{\mathrm{T}}\right)$ y el índice de condición somática $\left(\mathrm{K}_{\mathrm{S}}\right)$ mostraron variación mensual significativa únicamente para los machos del AD. En general, estos índices mostraron un incremento continuo de noviembre a marzo y una disminución lenta que inició en abril y mayo. 
The condition indices evaluated during the year provided higher values for the MA fish. Males presented higher values than females in both environments. Fulton's general condition factor $\left(\mathrm{K}_{\mathrm{F}}\right)$, the total condition factor $\left(\mathrm{K}_{\mathrm{T}}\right)$, and the somatic condition factor $\left(\mathrm{K}_{\mathrm{S}}\right)$ showed a significant monthly variation only for the males fished in $\mathrm{FW}$. In general, these indices presented a continuous increase from November to March and a slow decrease starting in April and May. The monthly $\mathrm{K}_{\mathrm{F}}$ values for the $\mathrm{FW}$ males presented significant differences, with a maximum in February (10.1) and a minimum in March (0.30) (KW = 95.3, $P<0.01)$. No significant differences were observed for the $\mathrm{FW}$ females, and the $\mathrm{K}_{\mathrm{F}}$ values varied from 0.47 to 12.1 ( $\mathrm{KW}=14.7, P=0.98$ ). The same situation was observed for males and females from MA, with values oscillating from 0.48 to $13.0(\mathrm{KW}=13.2$, $P=0.15)$ and from 0.45 to $13.1(\mathrm{KW}=8.27, P=0.60)$, respectively (fig. 5a). Monthly $\mathrm{K}_{\mathrm{T}}$ values for the $\mathrm{FW}$ males varied significantly from 0.011 to $0.034(\mathrm{KW}=75.0$, $P<0.01)$. No statistically significant differences were observed during the year for the other organisms of all the groups; the $\mathrm{K}_{\mathrm{T}}$ values for the $\mathrm{FW}$ females varied from 0.009 to $0.023(\mathrm{KW}=13.2, P=0.15)$, and the values for the MA males and females varied from 0.160 to $0.384(\mathrm{KW}=15.0$, $P=0.06)$ and from 0.039 to $0.105(\mathrm{KW}=1.8, P=0.99)$, respectively (fig. $5 \mathrm{~b}$ ). The $\mathrm{K}_{\mathrm{S}}$ values were similar to the $\mathrm{K}_{\mathrm{T}}$ values. For the $\mathrm{FW}$ males, the monthly $\mathrm{K}_{\mathrm{S}}$ values varied significantly between 0.011 and $0.034(\mathrm{KW}=75.0, P<0.01)$. In contrast, the FW females presented no significant differences during the year, with $\mathrm{K}_{\mathrm{S}}$ values ranging from 0.009 to 0.024 $(\mathrm{KW}=15.7, P=0.71)$. A similar situation was recorded for the males and females from MA, with values ranging from 0.0159 to $0.382(\mathrm{KW}=14.9, P=0.09)$ and from 0.039 to $0.103(\mathrm{KW}=2.9, P=0.98)$, respectively.

The greatest $\mathrm{I}_{\mathrm{G}}$ values were recorded for both sexes from MA, and only occasionally for some females and males from FW (fig. 5c). In MA, both sexes presented a highly significant variation in $\mathrm{I}_{\mathrm{G}}$ during the year. Males showed maximum values between June and August (KW $=99.3, P<0.001$ ), whereas females had maximum values during a longer period, from April to September $(\mathrm{KW}=70.0, P<0.001)$. The males presented low values in FW; however, significant differences were recorded and the maximum values occurred in May and September $(\mathrm{KW}=69.1, P<0.001)$. The females presented no significant differences during the year $(\mathrm{KW}=$ 14.2, $P=0.115)$. The logistic analysis carried out for MA estimated that the sizes at which $50 \%$ of the fish were mature $\left(\mathrm{L}_{50}\right)$ were $80 \mathrm{~cm}$ TL for males and $85 \mathrm{~cm}$ TL for females. In $\mathrm{FW}$, the $\mathrm{L}_{50}$ values were $78.7 \mathrm{~cm}$ TL for males and $89 \mathrm{~cm} \mathrm{TL}$ for females.

The physicochemical parameters varied seasonally (table 1). The minimum temperature values were recorded at the start and end of the year, while the maximum values were recorded from June to September. Salinity, electric conductivity, and total dissolved solids varied according to the dry and rainy seasons, with the minimum values during the rainy

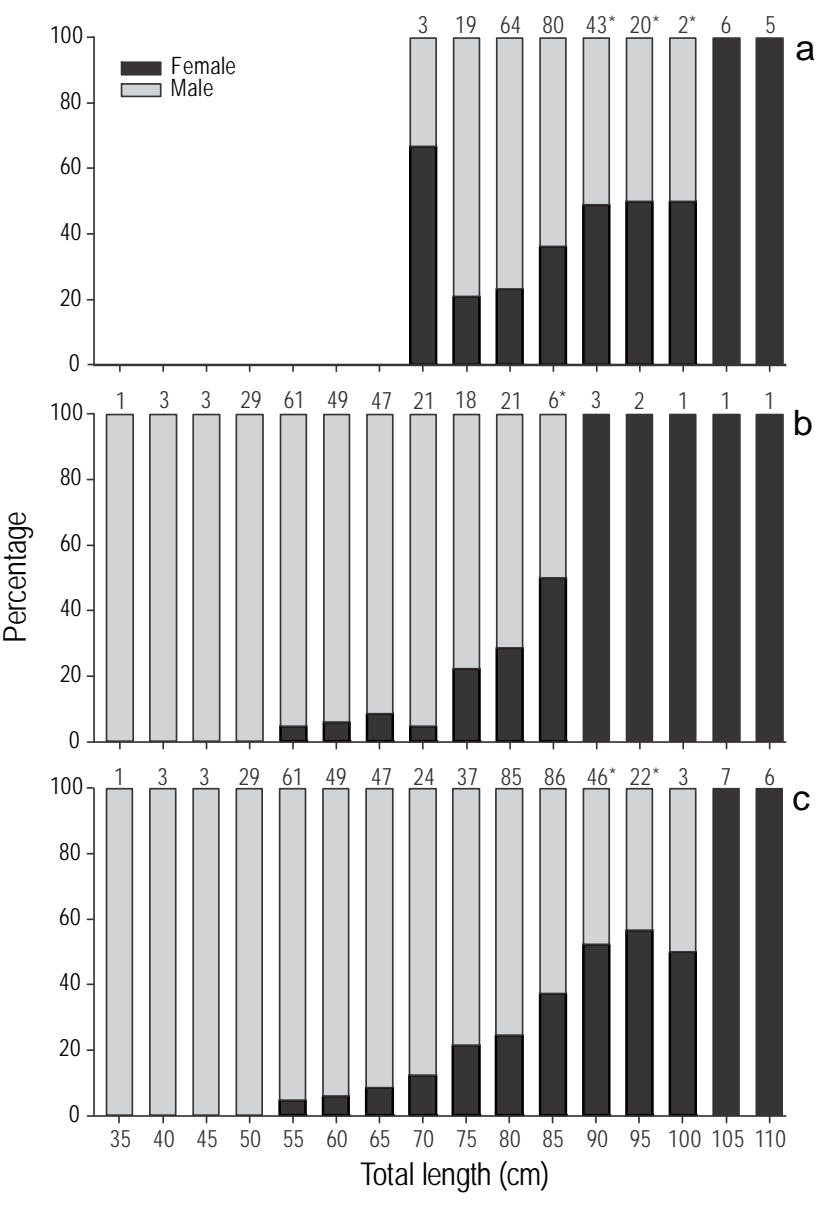

Figure 3. Sex ratio per size range for Centropomus undecimalis from a marine environment (a) and a freshwater environment (b), and for all the fish (c). The number above the bar corresponds to the sample size. $*$ No significant difference with respect to the $1: 1$ sex ratio (M:F) using the $\chi^{2}$ test $(P>0.05)$.

Figura 3. Proporción sexual por intervalo de talla para Centropomus undecimalis provenientes del ambiente marino (a) y del ambiente dulceacuícola (b), y para todos los peces (c). El número sobre la barra corresponde al tamaño de muestra. * No hay diferencias significativas con respecto a la proporción sexual 1:1 (M:H) utilizando la prueba $\chi^{2}(P>0.05)$.

Los valores mensuales de $\mathrm{K}_{\mathrm{F}}$ para los machos del AD mostraron diferencias significativas, con un máximo en febrero $(10.1)$ y un mínimo en marzo $(0.30)(\mathrm{KW}=95.3, P<0.01)$. No se observaron diferencias significativas para las hembras del $\mathrm{AD}$, y los valores de $\mathrm{K}_{\mathrm{F}}$ variaron de 0.47 a 12.1 $(\mathrm{KW}=14.7, P=0.98)$. Una situación similar se observó para los machos y las hembras del $\mathrm{AM}$, con valores que oscilaron de 0.48 a $13.0(\mathrm{KW}=13.2, P=0.15)$ y de 0.45 a $13.1(\mathrm{KW}=8.27, P=0.60)$, respectivamente (fig. 5a). Los valores mensuales de $\mathrm{K}_{\mathrm{T}}$ para los machos del $\mathrm{AD}$ variaron significativamente de 0.011 a $0.034(\mathrm{KW}=75.0, P<0.01)$. No se observaron diferencias significativas durante el año para el resto de los grupos; los valores de $\mathrm{K}_{\mathrm{T}}$ para las hembras 

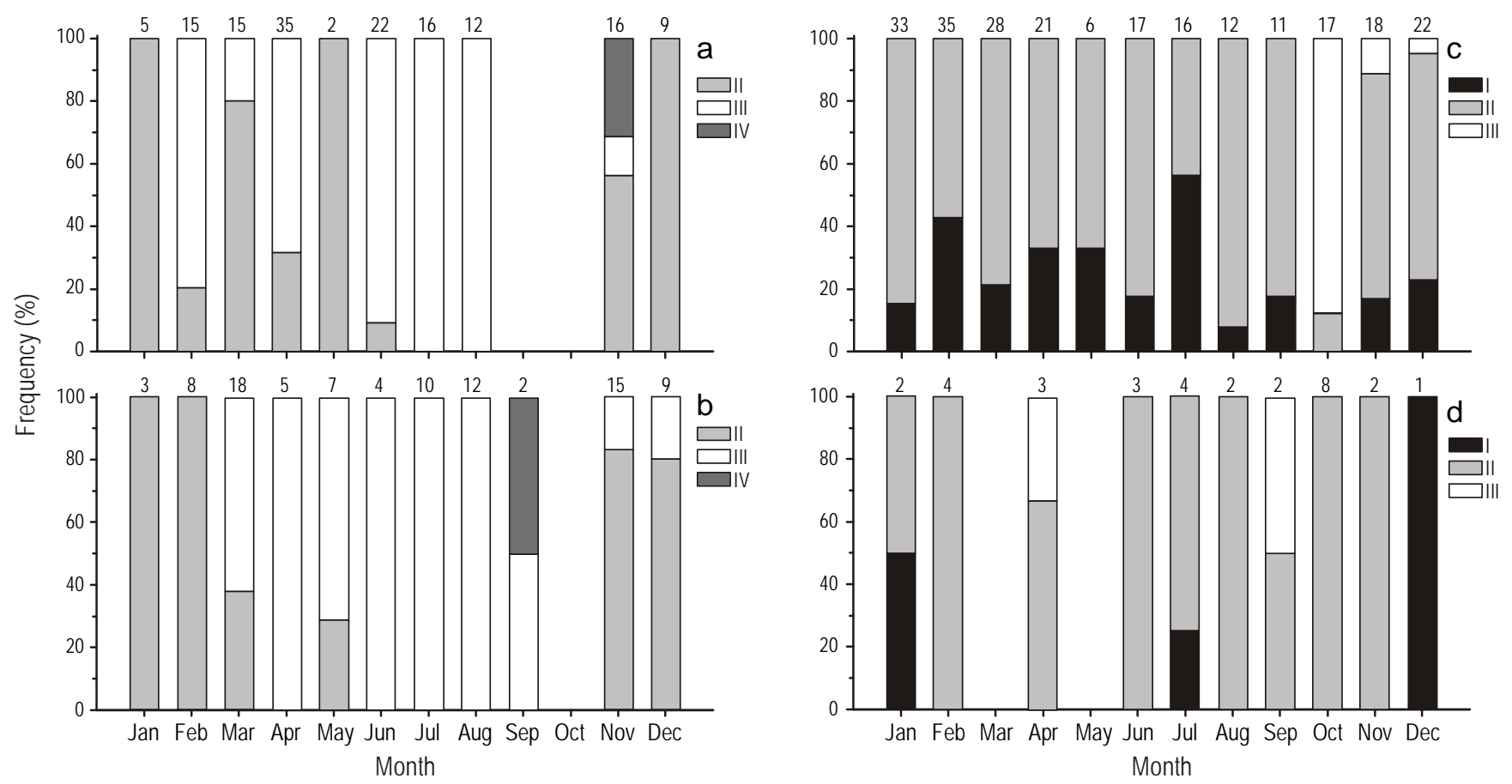

Figure 4. Monthly frequency distribution of macroscopic gonad stages of Centropomus undecimalis: males (a) and females (b) from a marine environment, and males (c) and females (d) from a freshwater environment. Stages: I, immature; II, developing; III, spawning capable; and IV, regressing. The number above the bar corresponds to the sample size.

Figura 4. Distribución mensual de frecuencias de las etapas macroscópicas de madurez gonádica de Centropomus undecimalis: machos (a) y hembras (b) del ambiente marino, y machos (c) y hembras (d) del ambiente dulceacuícola. Etapas: I, inmaduros; II, en desarrollo; III, capaz de desovar; y IV, en regresión. El número sobre la barra corresponde al tamaño de muestra.

months and the maximum values during the dry, hot months. The dissolved oxygen concentration varied with respect to depth; low values were recorded near the bottom, with a minimum in December in MA and in August in FW.

\section{DISCUSSION}

This study reports the presence of both sexes of $C$. undecimalis in the spawning capable macroscopic maturity stage in FW, far from the reported spawning areas in the sea. This information represents an important contribution to the biology of the species, as previous studies carried out in these localities have reported common snooks in the spawning capable stage only in MA, and only early stages in FW. This suggests that the gonadal maturation of $C$. undecimalis in $\mathrm{FW}$ was restricted (Chávez-Lomelí et al. 1989; Perera-García et al. 2008, 2011). However, our results suggest a variant in the reproductive strategy of the common snook involving a physiological tolerance mechanism that allows the adults that remain in FW to reach the spawning capable stage. This strategy allows $C$. undecimalis to benefit from feeding and refuge resources in freshwater and brackish habitats (Adams et al. 2006, Brennan et al. 2008, Milton 2009) while gonads develop. del AD variaron de 0.009 a $0.023(\mathrm{KW}=13.2, P=0.15)$ y para los machos y hembras del AM variaron de 0.160 a 0.384 $(\mathrm{KW}=15.0, P=0.06)$ y de 0.039 a $0.105(\mathrm{KW}=1.8, P=$ 0.99 ), respectivamente (fig. $5 b$ ). Los valores de $K_{S}$ fueron similares a los de $\mathrm{K}_{\mathrm{T}}$. Para los machos del AD, los valores mensuales de $\mathrm{K}_{\mathrm{S}}$ variaron significativamente entre 0.011 y $0.034(\mathrm{KW}=75.0, P<0.01)$. En contraste, las hembras del AD no mostraron diferencias significativas durante el año, con valores de $\mathrm{K}_{\mathrm{S}}$ que oscilaron de 0.009 a $0.024(\mathrm{KW}=15.7$, $P=0.71)$. Una situación similar se registró para los machos y las hembras del $\mathrm{AM}$, con valores que variaron de $0.0159 \mathrm{a}$ $0.382(\mathrm{KW}=14.9, P=0.09)$ y 0.039 a $0.103(\mathrm{KW}=2.9, P=$ $0.98)$, respectivamente.

Los valores más altos del $\mathrm{I}_{\mathrm{G}}$ se registraron para ambos sexos del AM y ocasionalmente para algunas hembras y machos del AD (fig. 5c). En el AM, ambos sexos presentaron una variación altamente significativa en el $\mathrm{I}_{\mathrm{G}}$ durante el año. Los machos presentaron valores máximos entre junio $\mathrm{y}$ agosto $(\mathrm{KW}=99.3, P<0.001)$, mientras que las hembras presentaron valores máximos durante un periodo más prolongado, desde abril hasta septiembre $(\mathrm{KW}=70.0$, $P<0.001)$. Los machos presentaron valores bajos en el AD; sin embargo, se registraron diferencias significativas y los valores máximos se observaron en mayo y septiembre 

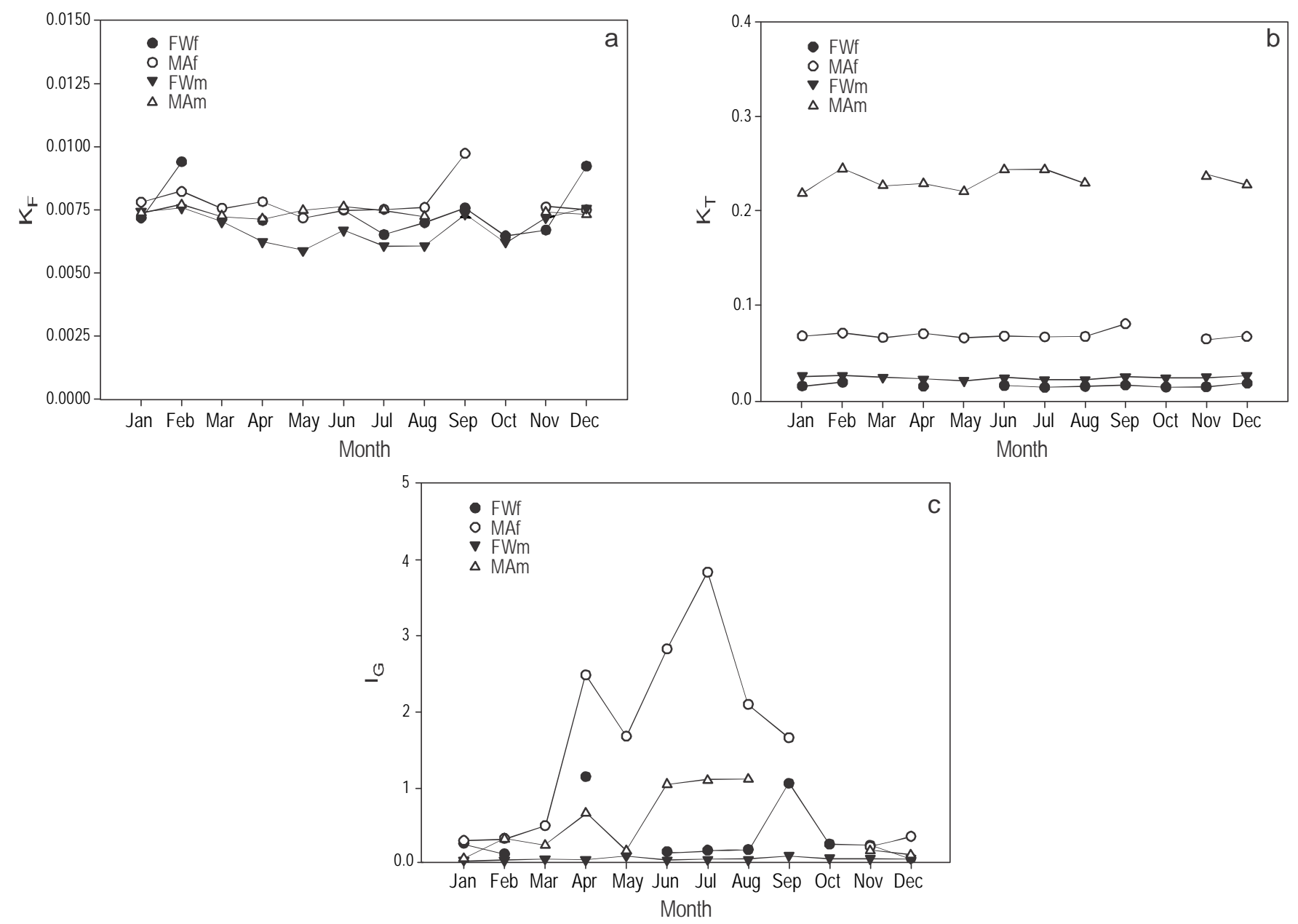

Figure 5. Monthly mean values of indexes for Centropomus undecimalis: (a) Fulton's condition factor $\left(\mathrm{K}_{\mathrm{F}}\right)$, (b) total condition factor $\left(\mathrm{K}_{\mathrm{T}}\right)$, and (c) gonadosomatic index $\left(\mathrm{I}_{\mathrm{G}}\right)$. FWf, females from a freshwater environment; MAf, females from a marine environment; FWm, males from a freshwater environment; and MAm, males from a marine environment.

Figura 5. Valores promedio mensuales del (a) índice de condición de Fulton $\left(\mathrm{K}_{\mathrm{F}}\right)$, (b) índice de condición total $\left(\mathrm{K}_{\mathrm{T}}\right)$ y $(\mathbf{c})$ índice gonadosomático $\left(\mathrm{I}_{\mathrm{G}}\right)$ para Centropomus undecimalis. FWf, hembras del ambiente dulceacuícola; MAf, hembras del ambiente marino; FWm, machos del ambiente dulceacuícola; y MAm, machos del ambiente marino.

The coincidence in the timing of the macroscopic stages in the two environments throughout the year indicates that the reproductive cycle of the common snook is synchronized, regardless of the environment in which it is found. This, combined with the capacity to migrate, suggests that when the fish reach spawning capable stage in either of these environments, they can migrate towards the spawning areas within the same reproductive season. Several studies have indicated that common snooks migrate easily (Adams et al. 2006, Brennan et al. 2008). In Florida, migrations of marine populations of common snooks have been observed covering distances up to $148 \mathrm{~km}$ (Stevens and Sulak 2001). In the localities of our study there are no specific reports of reproductive migrations of snooks, although fishery data indicate an annual migratory event between FW and MA (PereraGarcía et al. 2011). This idea is complemented with
$(\mathrm{KW}=69.1, P<0.001)$. Las hembras no presentaron diferencias significativas durante el año $(\mathrm{KW}=14.2, P=0.115)$. Según el modelo logístico realizado para los ejemplares del AM, se estimó que las tallas a las cuales el $50 \%$ de los peces alcanza la madurez $\left(\mathrm{L}_{50}\right)$ fueron $80 \mathrm{~cm} \mathrm{LT}$ para los machos y $85 \mathrm{~cm}$ LT para las hembras. En el $\mathrm{AD}$, los valores de $\mathrm{L}_{50}$ fueron $78.7 \mathrm{~cm} \mathrm{LT}$ para los machos y $89 \mathrm{~cm}$ LT para las hembras.

Los parámetros fisicoquímicos variaron estacionalmente (tabla 1). Los valores de temperatura mínima se registraron al inicio y al final del año, mientras que los valores máximos se registraron de junio a septiembre. La salinidad, la conductividad eléctrica y los sólidos disueltos totales variaron de acuerdo con las temporadas de secas y lluvias, con valores mínimos durante los meses lluviosos y los máximos durante los meses secos y calurosos. El oxígeno disuelto varió con 
Table 1. Monthly average of physicochemical parameters in interconnected marine (MA) and freshwater (FW) environments: temperature (T), dissolved oxygen (DO), salinity (S), electric conductivity (EC), and total dissolved solids (TDS).

Tabla 1. Promedio mensual de los parámetros fisicoquímicos en los ambientes marino (MA) y dulceacuícola (FW) interconectados: temperatura (T), oxígeno disuelto (DO), salinidad (S), conductividad eléctrica (EC) y sólidos disueltos totales (TDS).

\begin{tabular}{|c|c|c|c|c|c|c|c|c|c|c|}
\hline Month & \multicolumn{2}{|c|}{$\mathrm{T}\left({ }^{\circ} \mathrm{C}\right)$} & \multicolumn{2}{|c|}{$\mathrm{DO}\left(\mathrm{mg} \mathrm{L}^{-1}\right)$} & \multicolumn{2}{|c|}{$\mathrm{S}$} & \multicolumn{2}{|c|}{$\mathrm{EC}\left(\mathrm{mS} \mathrm{cm}^{-2}\right)$} & \multicolumn{2}{|c|}{ TDS $\left(\mathrm{g} \mathrm{L}^{-1}\right)$} \\
\hline January & 24.0 & 26.4 & 6.3 & 5.45 & 34.2 & $<2$ & 48.7 & 1.11 & 24.4 & 0.56 \\
\hline February & 25.1 & 25.8 & 6.4 & 6.03 & 33.7 & $<2$ & 49.2 & 1.10 & 24.6 & 0.55 \\
\hline March & 24.8 & 28.4 & 6.5 & 7.97 & 35.1 & $<2$ & 48.6 & 1.25 & 24.3 & 0.62 \\
\hline April & 27.0 & 28.2 & 5.6 & 6.45 & 34.2 & $<2$ & 43.8 & 0.90 & 21.3 & 0.44 \\
\hline June & 26.6 & 32.3 & 5.8 & 5.47 & 34.0 & $<2$ & 50.2 & 1.42 & 25.1 & 0.60 \\
\hline July & 28.6 & 30.4 & 6.3 & 3.81 & 32.5 & $<2$ & 42.0 & 1.00 & 20.7 & 0.50 \\
\hline August & 27.2 & 30.7 & 6.5 & 3.78 & 32.9 & $<2$ & 51.1 & 0.75 & 25.7 & 0.37 \\
\hline September & 29.4 & 30.3 & 5.7 & 4.10 & 31.9 & $<2$ & 48.6 & 0.73 & 24.3 & 0.21 \\
\hline October & 27.5 & 28.0 & 5.9 & 4.43 & 24.0 & $<2$ & 32.8 & 0.72 & 16.4 & 0.36 \\
\hline
\end{tabular}

information indicating that individuals from both localities belong to the same population, presenting a high migratory flux value at the genetic level (Hernández-Vidal et al. 2014). Ayala-Pérez et al. (2012) emphasize that fishes have developed a life cycle strategy linked to environmental variability at a spatial and temporal scale. In this regard, reproductive migrations are valuable when seeking a habitat that favors the success of the progeny (Milton 2009). In the case of Morone saxatilis, a one-week reproductive migration has been observed between rivers and estuaries, covering a distance of up to $165 \mathrm{~km}$ (Carmichael et al. 1998). The migrations of Gadus morhua cover several hundred kilometers (Jørgensen et al. 2008), while Polyprion americanus can travel 1000 to $1500 \mathrm{~km}$ (Peres and Klippel 2003) in the same reproductive season. Information on migrations of several species, including common snooks in Florida, and similarities in genetic allele frequency for fishes from our study area, allow us to suggest that organisms of $C$. undecimalis, in spawning capable stage, can travel more than $300 \mathrm{~km}$ from the Grijalva-Usumacinta system to the spawning areas located in the Gulf of Mexico. However, Trotter et al. (2012) suggested that up to $40 \%$ of $C$. undecimalis individuals do not complete the annual spawning migration that takes place in coastal Florida. These authors do not mention the gonadal condition of the resident or non-migrant fish, so it is not possible to define the condition of gonadal development at the time of this occurrence. Gonadal maturation in FW with no possibility to spawn supposes a waste in the fish energy budget and supports the idea of spawning capable snooks migrating seaward to spawn (Grier 1985, Taylor et al. respecto a la profundidad; los valores más bajos se registraron cerca del fondo, con un mínimo en diciembre en el AM y en agosto en el AD.

\section{DISCUSIÓN}

Este estudio documenta la presencia de ambos sexos de C. undecimalis en la etapa de madurez macroscópica capaz de desovar en $\mathrm{AD}$, lejos de las áreas de desove en el mar que se han registrado. Esta información representa una contribución importante a la biología de la especie, ya que estudios previos realizados en estas localidades han registrado al robalo común en la etapa capaz de desovar sólo en AM, y únicamente en etapas tempranas en el AD. Esto se interpretaba como que la madurez gonádica de C. undecimalis en AD estaba restringida (Chávez-Lomelí et al. 1989, Perera-García et al. 2008, 2011). Sin embargo, nuestros resultados sugieren una variante en la estrategia reproductiva del robalo común que involucra mecanismos de tolerancia fisiológica que permiten a los adultos que se mantienen en $\mathrm{AD}$ alcanzar la etapa capaz de desovar. Esta estrategia permite a C. undecimalis beneficiarse de las fuentes de alimento y refugio en hábitats dulceacuícolas y salobres (Adams et al. 2006, Brennan et al. 2008, Milton 2009) mientras las gónadas se desarrollan.

La coincidencia en la temporalidad de las etapas macroscópicas en los dos ambientes durante el año indica que el ciclo reproductor del robalo común está sincronizado, independientemente del ambiente en donde se encuentre. Lo anterior, combinado con la capacidad migratoria, sugiere que cuando los peces alcanzan la etapa capaz de desovar en 
1998, Perera-García et al. 2011). This requires evaluation by studying migrations among environments in the Grijalva-Usumacinta system.

The actively spawning subphase was observed only in MA. This coincides with reports supporting spawning of $C$. undecimalis at sea (Grier 1985, Tucker 1987, Taylor et al. 1998, Perera-García et al. 2011, Andrade et al. 2013). According to our data, spawning frequently occurs during the months of higher salinity and temperature. In contrast, no reports have recorded common snook spawning in FW. The fact that $C$. undecimalis depends on MA to spawn may be related to limitations in the production and survival of both gametes and embryos in FW. Coward et al. (2002) reported that low salinities cause a loss of gamete viability and the death of embryos in fish species that spawn in marine habitats, due to a deficient regulation of cellular osmolarity. In contrast with this apparent incapacity of the snooks to spawn in FW, the euryhaline Micropogonias furnieri spawns in different salinity environments and favors the success of the progeny by providing a valuable strategy for the use of resources and the possibility of colonizing new habitats (Militelli et al. 2013).

The increase in frequency of young males in the spawning capable stage in FW during down-river migrations, and the increase in frequency of young adults in MA during the following months, suggests that recruitment to the reproductive stock takes place in MA. This is shown by higher condition indices in MA than in FW and could reflect the need for obtaining energy sources in preparation for the approaching spawning season (Lucano-Ramírez et al. 2014). This incorporation coincides with macroscopic gonadal features and $\mathrm{I}_{\mathrm{G}}$ in fishes inhabiting both environments. It is possible that the rainy and flooding season in $\mathrm{FW}$ induces migratory behaviors and the recruitment of snooks to MA. This has been reported for the Atlantic coast of Guatemala, where an increase in the number of young specimens arriving from the rivers has been observed (Andrade et al. 2013). This pattern has also been suggested for several species of migratory fish in South American rivers, suggesting that they take advantage of the fluvial connections generated among habitats to become established as breeders (Agostinho et al. 2004, Guerrero et al. 2009).

The analysis of the size, weight, sex composition, and TW-TL relationship of $C$. undecimalis suggests that there is a sequence in growth that associates sex ratio changes and the optimal use of resources in the different environments. This sequence starts with a great abundance of young males in $\mathrm{FW}$ that migrate to $\mathrm{MA}$ as mature males, and the presence of a few young females in FW (possibly with a recent sexual reversion) and an abundance of large females in MA. This sequence agrees with a sequential hermaphroditism that allows a change from male to female as the snooks (and other fish species) grow, favoring a prevalence of large females (Taylor et al. 2000, Perera-García et al. 2011, Andrade et al. 2013, Hadj-Taieb et al. 2013). It is also related to the role of cualquiera de los dos ambientes, pueden migrar hacia las áreas de desove dentro de la misma temporada reproductora. Diversos estudios indican que el robalo común migra fácilmente (Adams et al. 2006, Brennan et al. 2008). En Florida, las poblaciones del robalo común realizan migraciones cubriendo distancias de más de 148 km (Stevens y Sulak 2001). En las localidades de nuestro estudio no existen registros específicos de migraciones reproductivas de robalos, aunque los datos pesqueros indican un evento migratorio anual entre AD y AM (Perera-García et al. 2011). Esta idea es complementada con la información que indica que los individuos de ambas localidades provienen de la misma población, mostrando un alto valor de flujo migratorio a nivel genético (Hernández-Vidal et al. 2014). Ayala-Pérez et al. (2012) enfatiza que los peces han desarrollado un ciclo de vida estratégicamente relacionado con la variabilidad ambiental a escala espacial y temporal. Al respecto, las migraciones reproductivas son valiosas en la búsqueda de hábitats que favorecen el éxito de la progenie (Milton 2009). En el caso de Morone saxatilis, se ha observado que la migración reproductiva entre ríos y estuarios se realiza en una semana, cubriendo una distancia de hasta $165 \mathrm{~km}$ (Carmichael et al. 1998). Las migraciones de Gadus morhua cubren varios cientos de kilómetros (Jørgensen et al. 2008), mientras que Polyprion americanus puede viajar entre $1000 \mathrm{y}$ 1500 km (Peres y Klippel 2003) durante la misma estación reproductora. La información sobre la migración de varias especies, incluyendo el robalo común en Florida, y la similitud en la frecuencia alélica a nivel genético para los peces de nuestras áreas de estudio, permiten sugerir que los ejemplares de $C$. undecimalis en la etapa capaz de desovar pueden viajar más de $300 \mathrm{~km}$ en el sistema Grijalva-Usumacinta hacia las áreas de desove localizadas en el golfo de México. Sin embargo, Trotter et al. (2012) sugieren que en la costa de Florida, hasta el $40 \%$ de individuos de C. undecimalis no completa la migración anual para el desove. Estos autores no mencionan la condición gonádica de los peces residentes o no-migrantes, por lo cual no es posible definir la condición gonádica al momento que ocurre. La maduración gonádica en el AD sin posibilidad de desove supone un desperdicio en el presupuesto energético y apoya la idea de que los robalos capaces de desovar migran hacia el AM para desovar (Grier 1985, Taylor et al. 1998, Perera-García et al. 2011). Esto requiere evaluarse estudiando las migraciones entre los ambientes en el sistema Grijalva-Usumacinta.

La subetapa desove activo fue registrada únicamente en el AM. Esto coincide con los registros que indican que el desove de C. undecimalis ocurre en el mar (Grier 1985, Tucker 1987, Taylor et al. 1998, Perera-García et al. 2011, Andrade et al. 2013). De acuerdo con nuestros datos, el desove ocurre con mayor frecuencia en los meses de alta salinidad y temperatura. En contraste, no hay documentos que registren el desove del robalo común en el AD. El hecho de que $C$. undecimalis dependa del AM para desovar puede estar relacionado con limitaciones en la producción y 
freshwater and brackish habitats in the early development stages of $C$. undecimalis, which provide protection and food during the juvenile stages, after which the adults migrate seaward to spawn (McMichael et al. 1989, Peterson and Gilmore 1991, Aliaume et al. 2000, Brennan et al. 2008). These characteristics of the snook's life cycle could explain the presence of a high proportion of males of small size and weight found in FW, followed by a later increase in the proportion of females, with fish of greater size and weight in MA. Our findings agree with sex ratio values (M:F) reported by several studies. For example, our value of 7.6:1 for FW is similar to the value of 6.2:1 reported by Perera-García et al. (2011) for the same area, and our value for MA coincides with that obtained by Perera-García et al. $(2008,2011,2013)$ for the same area and by Andrade et al. (2013) for the Atlantic coast of Guatemala (1.5:1 in all cases). However, part of the variation recorded for the sizes and sex ratios could be related to different considerations like fish behavior and fishing gear used. Variations in sex ratio data for Gobius paganellus and Pennahia anea have been reported to be related to the seasonality of schooling for feeding and spawning, and might be affected by the fishing gear used (Tuuli et al. 2011, Hajji et al. 2012, Lucano-Ramírez et al. 2014).

The results of this study provide new information on the reproductive biology of the common snook along the environmental gradient characterizing its distribution range, and suggest a variant in the reproductive strategy that has traditionally been described for $C$. undecimalis. This strategy suggests reproductive synchronization and capacity to reach advanced stages of gonadal maturity in FW, a situation not previously reported. The sex composition and morphometric data suggest that young fish prefer FW and adults prefer MA. As this species represents an important fishery resource in the region, with fisheries established in both FW and MA, this information should be taken into account when developing programs for the conservation and sustainable management of the resource, considering the complex biological characteristics of the species and the vulnerability of the migratory groups in FW and the large females as the main targets of the fisheries.

\section{ACKNOWLEDGMENTS}

This research is a component of the AquaFish Collaborative Research Support Program (CRSP), supported by the US Agency for International Development (USAID, award number CA/LWA No. EPP-A-00-06-0012-00) and by contributions from participating institutions. The AquaFish CRSP accession number is 1420 . This study was also partially supported by the Universidad Juárez Autónoma de Tabasco (UJAT, PFICA research program). We thank Moisés González and Alejandro Mcdonal for field support, fishers from the Balancan and Centla municipalities, and Hilda María Díaz López for providing the map of the study site. supervivencia tanto de gametos como de embriones en el AD. Coward et al. (2002) indicaron que la baja salinidad causa la pérdida de la viabilidad de los gametos y la muerte de los embriones de especies de peces que desovan en hábitats marinos, debido a deficiencias en la regulación de la osmolaridad celular. En contraste con esta aparente incapacidad de los robalos para desovar en ambientes dulceacuícolas, el pez eurihalino Micropogonias furnieri desova en ambientes de diferente salinidad, con lo que favorece el éxito de la progenie al proveer de una estrategia valiosa en el aprovechamiento de recursos y la posibilidad de colonizar nuevos hábitats (Militelli et al. 2013).

El incremento en la frecuencia de machos jóvenes en la etapa capaz de desovar en el $\mathrm{AD}$ durante las migraciones río abajo, así como el incremento en la frecuencia de jóvenes adultos en el AM durante los meses consecutivos, sugiere que el reclutamiento a la población de reproductores se realiza en el AM. Esto se observa en el incremento de los índices de condición en $\mathrm{AM}$ respecto a $\mathrm{AD}$ y puede reflejar la necesidad de obtener fuentes energéticas en preparación ante la proximidad de la migración reproductiva (Lucano-Ramírez et al. 2014). Esta incorporación coincide con las características gonádicas y el $\mathrm{I}_{\mathrm{G}}$ en los ejemplares que habitan ambos ambientes. Es posible que la temporada de lluvias e inundaciones en el $\mathrm{AD}$ promueva la conducta migratoria y el reclutamiento de los robalos al AM. Se ha registrado una situación similar para robalos en la costa Atlántica de Guatemala, donde se ha observado un incremento en el número de adultos jóvenes provenientes de los ríos (Andrade et al. 2013). Este patrón se ha propuesto para varias especies de peces migratorios en ríos de América del Sur, sugiriendo que las conexiones fluviales generadas entre los hábitats presentan ventajas en su establecimiento como reproductores (Agostinho et al. 2004, Guerrero et al. 2009).

El análisis de las tallas, el peso, la composición sexual y la relación PT-LT de C. undecimalis sugiere que hay una secuencia en el crecimiento que asocia los cambios en la proporción sexual y el aprovechamiento óptimo de los recursos en diferentes ambientes. Esta secuencia inicia con la gran abundancia de machos jóvenes en el AD que migran al AM como machos maduros, la presencia de pocas hembras jóvenes en el $\mathrm{AD}$ (posiblemente con una reversión sexual reciente) y la abundancia de hembras grandes en el AM. Esta secuencia concuerda con el hermafroditismo secuencial que permite el cambio de macho a hembra conforme crecen los robalos (y otras especies de peces), favoreciendo la prevalencia de hembras grandes (Taylor et al. 2000, Perera-García et al. 2011, Andrade et al. 2013, Hadj-Taieb et al. 2013). Esto se relaciona también con el rol de los hábitats dulceacuícolas y salobres durante las etapas tempranas de desarrollo de C. undecimalis, los cuales proporcionan protección y alimento durante la etapa juvenil, previo a su migración como adultos al AM para desovar (McMichael et al. 1989, Peterson y Gilmore 1991, Aliaume et al. 2000, Brennan et al. 2008). Estas características del ciclo de vida de los robalos puede 


\section{REFERENCES}

Adams AJ, Wolfe RK, Pine WE, Thornton BL. 2006. Efficacy of PIT tags and an autonomous antenna system to study the juvenile life stage of an estuarine-dependent fish. Estuar. Coasts 29: 311-317. http://dx.doi.org/10.1007/BF02781999

Agostinho AA, Gomes LC, Veríssimo S, Okada EK. 2004. Flood regime, dam regulation and fish in the upper Paraná River: Effects on assemblage attributes, reproduction and recruitment. Rev. Fish Biol. Fish. 14: 11-19. http://dx.doi.org/10.1007/s11160-004-3551-y

Aliaume C, Zerbi A, Joyeux JC, Miller JM. 2000. Growth of juvenile Centropomus undecimalis in a tropical island. Environ. Biol. Fish. 59: 299-308.

http://dx.doi.org/10.1023/A:1007662611839

Andrade H, Santos J, Taylor R. 2013. Life-history traits of the common snook Centropomus undecimalis in a Caribbean estuary and large-scale biogeographic patterns relevant to management. J. Fish Biol. 82: 1951-1974. http://dx.doi.org/10.1111/jfb.12123

Ayala-Pérez LA, Terán-González GJ, Ramos-Miranda J, FloresHernández D. 2012. Interannual changes in the fish community abundance on the west coast of Campeche, Mexico. Cienc. Mar 38: $395-410$. http://dx.doi.org/10.7773/cm.v38i2.1987

Bagenal T, Tesch FW. 1978. Age and growth. In: Bagenal T (ed.), Methods for Assessment of Fish Production in Fresh Waters. Blackwell Scientific Publications. London, UK, pp. 101-136.

Brennan NP, Walters CJ, Leber KM. 2008. Manipulations of stocking magnitude: Addressing density-dependence in a juvenile cohort of common snook (Centropomus undecimalis). Rev. Fish. Sci. 16: 215-227. http://dx.doi.org/10.1080/10641260701689022

Brown-Peterson NJ, Wyanski DM, Saborido-Rey F, Macewicz BJ, Lowerre-Barbieri SK. 2011. A standardized terminology for describing reproductive development in fishes. Mar. Coast. Fish. 3: $52-70$.

http://dx.doi.org/10.1080/19425120.2011.555724

Carmichael JT, Haeseker SL, Hightower JE. 1998. Spawning migration of telemetered striped bass in the Roanoke River, North Carolina. Trans. Am. Fish. Soc. 127: 286-297. http://dx.doi.org/10.1577/15488659(1998) $127<0286$ :SMOTSB $>2.0 . \mathrm{CO} ; 2$

Chávez-Lomelí MO, Mattheeuws AE, Pérez-Vega MH. 1989. Biología de los peces del río San Pedro en vista de determinar su potencial para la piscicultura. INREB-FUCID, Veracruz, México. 222 pp.

Coward K, Bromage NR, Hibbitt O, Parrington J. 2002. Gamete physiology, fertilization and egg activation in teleost fish. Rev. Fish Biol. Fish. 12: 33-58. http://dx.doi.org/10.1023/A:1022613404123

Gayanilo F, Pauly D. 1997. Stock Assessment Tools Reference Manual. FAO-ICLARM, Rome, 255 pp.

Grier HJ. 1985. Reproduction of the snook, Centropomus undecimalis: Structure of the testis I reproductive males. In: Proc. World Marine Soc. 16th Annual Meeting, 13-17 January, Florida, USA.

Guerrero HY, Cardillo E, Poleo G, Marcano D. 2009. Reproductive biology of freshwater fishes from the Venezuelan floodplains. Fish Physiol. Biochem. 35: 189-196.

http://dx.doi.org/10.1007/s10695-008-9249-7 explicar la presencia de una alta proporción de machos de talla y peso pequeños localizados en el $\mathrm{AD}$, seguido más tarde de un incremento en la proporción de hembras, con ejemplares de mayor talla y peso en el AM. Nuestros resultados coinciden con los valores de proporción sexual $(\mathrm{M}: \mathrm{H})$ registrados en varios estudios. Por ejemplo, nuestro valor de 7.6:1 para el AD es similar al valor de 6.2:1 registrado por Perera-García et al. (2011) para la misma zona de estudio, y nuestro valor para el AM coincide con el obtenido por Perera-García et al. $(2008,2011,2013)$ para la misma zona de estudio y por Andrade et al. (2013) para la costa atlántica de Guatemala (1.5:1 en todos los casos). Sin embargo, parte de la variación registrada para las tallas y la proporción sexual puede deberse a diferentes consideraciones, tales como la conducta de los organismos y el tipo de arte de pesca empleado. Las variaciones en la proporción sexual que se han registrado para Gobius paganellus y Pennahia anea podrían estar relacionadas a una combinación de factores como agregaciones estacionales para la alimentación y desove, y el arte de pesca empleado (Tuuli et al. 2011, Hajji et al. 2012, Lucano-Ramírez et al. 2014).

Los resultados de este estudio proporcionan nuevos elementos sobre la biología reproductiva del robalo común a lo largo del gradiente ambiental que caracteriza su intervalo de distribución, y sugieren una variante en la estrategia reproductiva que tradicionalmente ha sido descrita para C. undecimalis. Esta estrategia sugiere sincronización reproductiva y capacidad para alcanzar etapas avanzadas de madurez gonádica en el $\mathrm{AD}$, una condición no registrada previamente. Los datos morfométricos y composición sexual sugieren que los peces jóvenes prefieren el $\mathrm{AD}$ y los adultos el AM. Al representar esta especie un recurso pesquero importante en la región, con pesquerías establecidas tanto en FW y MA, esta información deberá tomarse en cuenta en el desarrollo de programas para la conservación y manejo sustentable del recurso, considerando la complejidad de las características del ciclo biológico de la especie y la vulnerabilidad de los grupos migrantes del AD y las hembras grandes como el principal objetivo de las pesquerías.

\section{Agradecimientos}

Este estudio es un componente del AquaFish Collaborative Research Support Program (CRSP), que es apoyado por la Agencia Para el Desarrollo Internacional de los Estados Unidos (USAID, número de concesión CA/LWA No. EPP-A00-06-0012-00) y por las contribuciones de instituciones participantes. El número de acceso del AquaFish CRSP es 1420. Este estudio fue parcialmente apoyado con financiamiento de la Universidad Juárez Autónoma de Tabasco (UJAT, programa PFICA). Agradecemos a Moisés González y Alejandro Mcdonal el apoyo en campo, a los pescadores de los municipios de Balancan y Centla, y a Hilda María Díaz López el haber proveído el mapa del sitio de estudio. 
Jørgensen C, Dunlop ES, Opdal AF, Fiksen Ø. 2008. The evolution of spawning migrations: State dependence and fishing-induced changes. Ecology 89: 3436-3448. http://dx.doi.org/10.1890/07-1469.1

Hadj-Taieb A, Ghorbel M, Hadj-Hamida NB, Jarboui O. 2013. Sex ratio, reproduction, and growth of the gilthead sea bream, Sparus aurata (Pisces: Sparidae), in the Gulf of Gabes, Tunisia. Cienc. Mar 39: 101-112. http://dx.doi.org/10.7773/cm.v39i1.2146

Hajji F, Ouannes-Ghorbel A, Ghorbel M, Jarboui O. 2012. Reproductive biology of the rock goby, Gobius paganellus (Actinopterygii: Perciformes: Gobiidae), on the southern Tunisian coast (Gulf of Gabes). Cienc. Mar. 38: 505-515. http://dx.doi.org/10.7773/cm.v38i3.2147

Hernández-Vidal U, Lesher-Gordillo J, Contreras-Sánchez WM, Chiappa-Carrara FX. 2014. Genetic variability of the common snook Centropomus undecimalis (Perciformes: Centropomidae) in connected marine and riverine environments. Rev. Biol. Trop. 62: 627-636. http://dx.doi.org/10.15517/rbt.v62i2.11072

McMichael RH, Peters KM, Parsons GR. 1989. Early life history of the snook, Centropomus undecimalis, in Tampa Bay Florida. NE Gulf Sci. 10: 113-126.

Militelli MI, Rodrigues KA, Cortés F, Macchi GJ. 2013. Influence of environmental factors on the spawning of sciaenids in the Buenos Aires Coastal Zone, Argentina. Cienc. Mar. 39: 55-68. http://dx.doi.org/10.7773/cm.v39i1.2176

Milton DA. 2009. Living in two worlds: Diadromous fishes, and factors affecting population connectivity between tropical rivers and coasts. In: Nagelkerken I (ed.), Ecological Connectivity among Tropical Coastal Ecosystems. Springer, Netherlands, pp. 325-355.

Lucano-Ramírez G, Ruiz-Ramírez S, González-Sanson S, CeballosVázquez BP. 2014. Reproductive biology of the yellow snapper, Lutjanus argentiventris (Pisces, Lutjanidae), from the Mexican central Pacific. Cienc. Mar. 40: 33-44. http://dx.doi.org/10.7773/cm.v40i1.2325

Perera-García MA, Mendoza-Carranza M, Páramo-Delgadillo S. 2008. Dinámica reproductiva y poblacional del robalo, Centropomus undecimalis (Perciformes: Centropomidae), en barra San Pedro, Centla, México. Univ. Cienc. 24: 49-59.

Perera-García MA, Mendoza-Carranza M, Contreras-Sánchez WM, Huerta-Ortiz M, Pérez-Sánchez E. 2011. Reproductive biology of common snook Centropomus undecimalis (Perciformes: Centropomidae) in two tropical habitats. Rev. Biol. Trop. 59: 669-681.

http://dx.doi.org/10.15517/rbt.v0i0.3131
Perera-García MA, Mendoza-Carranza M, Contreras-Sánchez WM, Ferrara A, Huerta-Ortiz M, Hernández-Gómez RE. 2013. Comparative age and growth of common snook Centropomus undecimalis (Pisces: Centropomidae) from coastal and riverine areas in southern Mexico. Rev. Biol. Trop. 61: 807-819. http://dx.doi.org/10.15517/rbt.v61i2.11224

Peres MB, Klippel S. 2003. Reproductive biology of southwestern Atlantic wreckfish Polyprion americanus (Teleostei: Polyprionidae). Environ. Biol. Fish. 68: 163-173. http://dx.doi.org/10.1023/B:EBFI.0000003845.43700.29

Peterson MS, Gilmore RG. 1991. Eco-physiology of juvenile snook Centropomus undecimalis (Bloch): Life-history implications. Bull. Mar. Sci. 48: 46-57.

Stevens PW, Sulak KJ. 2001. Egress of adult sport fish from an estuarine reserve within Merritt Island National Wildlife Refuge, Florida. Gulf Mex. Sci. 2: 77-89.

Taylor RG, Grier HJ, Whittington JA. 1998. Spawning rhythms of common snook in Florida. J. Fish Biol. 53: 502-520. http://dx.doi.org/10.1111/j.1095-8649.1998.tb00998.x

Taylor RG, Whittington JA, Grier HJ, Crabtree RE. 2000. Age, growth, and protandric sex reversal in common snook Centropomus undecimalis from the east and west coasts of Florida. Fish Bull. 98: 612-624.

Tringali MD, Bert TM. 1996. The genetic stock structure in common snook Centropomus undecimalis. Can. J. Fish. Aquat. Sci. 53: 974-984. http://dx.doi.org/10.1139/f96-027

Tringali MD, Bert TM, Seyoum S. 1999. Genetic identification of centropomine fishes. Trans. Am. Soc. 1: 446-458. http://dx.doi.org/10.1577/15488659(1999) $128<0446$ :GIOCF $>2.0 . \mathrm{CO} ; 2$

Trotter AA, Blewett DA, Taylor RG, Stevens PW. 2012. Migrations of common snook from a tidal river with implications for skipped spawning. Trans. Am. Soc. 141: 1016-1025. http://dx.doi.org/10.1080/00028487.2012.675903

Tucker JW. 1987. Snook and tarpon snook culture and preliminary evaluation for commercial farming. Prog. Fish. Cult. 49: 49-57. http://dx.doi.org/10.1577/15488640(1987)49<49:SATSCA >2.0.CO;2

Tuuli CD, de Mitcheson YS, Liu M. 2011. Reproductive biology of the greyfin croaker Pennahia anea in the northern South China Sea. Ichthyol. Res. 58: 302-309. http://dx.doi.org/10.1007/s10228-011-0228-0

Vazzoler AE. 1996. Biologia da reproduçao de peixes Teleósteos: Teoría e práctica. EDUEM, Maringá, Brasil, 169 pp.

Zar JH. 1999. Biostatistical Analysis. Prentice Hall, New Jersey, $662 \mathrm{pp}$.

Received December 2013, accepted August 2014. 